\title{
The Svalbard Treaty and Norwegian Sovereignty
}

\author{
Øystein Jensen \\ University of South-Eastern Norway and Fridtjof Nansen Institute, Norway
}

\begin{abstract}
A hundred years ago on 9 February 2020, the Svalbard Treaty was adopted in Paris, granting Norway her long-standing ambition: full and absolute sovereignty over the Svalbard archipelago. After a brief review of the negotiations that preceded the Paris decision, this article examines the main elements of the Treaty: Norwegian sovereignty, the principle of non-discrimination and the terra nullius rights of other states, peaceful utilization, scientific research and environmental protection. Focus then shifts to Norway's policy towards Svalbard and the implementation of the Treaty's provisions: what have been the main lines of Norwegian Svalbard politics; what administrative structures have evolved; to what extent has Norwegian legislation been made applicable to Svalbard? Importantly, the article also addresses how widespread changes in international law that have taken place since 1920, particularly developments concerning the law of the sea, have brought to the forefront controversial issues concerning the geographic scope of the Treaty's application.
\end{abstract}

Keywords: Svalbard Treaty, sovereignty, non-discrimination, law of the sea

Responsible Editor: Nigel Bankes, Faculty of Law, University of Calgary, Canada

Received: May 2020; Accepted: June 2020; Published: December 2020

\section{Introduction}

The year 2020 marks a milestone in Norwegian polar history: on 9 February it was 100 years since the Treaty concerning the Archipelago of Spitsbergen (hereafter: Svalbard Treaty) was adopted in Paris. ${ }^{1}$ The Treaty recognizes Norway sovereignty over the Svalbard archipelago - all islands, islets and reefs between $74^{\circ}$ and $81^{\circ} \mathrm{N}$ and $10^{\circ}$ and $35^{\circ} \mathrm{E}$. The Svalbard Treaty came into force on 14 August 1925 . On the same day, the Svalbard Act also entered into force, ${ }^{2}$ making Svalbard the northernmost region of the Kingdom of Norway.

\footnotetext{
^Correspondence to: Øystein Jensen, email: ojensen@fni.no

(C) 2020 Øystein Jensen. This is an Open Access article distributed under the terms of the Creative Commons Attribution-NonCommercial 4.0 International License (https://creativecommons.org/licenses/by-nc/4.0/), allowing third parties to share their work (copy, distribute, transmit) and to adapt it, under the condition that the authors are given credit, that the work is not used for commercial purposes, and that in the event of reuse or distribution, the terms of this license are made clear. 
Before the Svalbard Treaty, Svalbard was no man's land in terms of international law - terra nullius. Various nationalities had conducted hunting, fishing and mining on and around the archipelago, but Svalbard was not subject to any state's sovereignty. Norway had long shown interest in Svalbard; and after the Swedish-Norwegian Union was dissolved in 1905, Norway initiated international negotiations aimed at clarifying the international legal status of the archipelago. However, the issue was not settled until after World War I, when the Allies concluded that clarification of Svalbard's international legal status was among the prerequisites for lasting peace in Europe. The resultant Svalbard Treaty granted Norway full and absolute sovereignty over this strategically important Arctic archipelago.

The Treaty also establishes an international legal framework for the exercise of Norwegian authority on Svalbard, with regulations on commercial activities and taxation, as well as military activities and research. Further, citizens of all treaty parties shall enjoy the same rights as Norwegians to engage in hunting, fishing and commercial activities on Svalbard. The Treaty is also one of the first international environmental protection agreements: Norway is to establish and enforce appropriate regulations to secure the animal and plant life found on Svalbard and in its adjacent waters.

This article focuses on major legal issues related to the Svalbard Treaty at its 100th anniversary. After a brief review of the negotiations leading up to the Paris decision in Section 2, the main elements of the Treaty are examined in Section 3. Focus then shifts to Norway's policy towards Svalbard in Section 4. Section 5 discusses controversies that have arisen between Norway and other states parties, including with regard to the geographic scope of the Treaty's application. Concluding remarks are offered in Section 6.

\section{Decision in Paris}

In terms of international law, the Svalbard archipelago was no man's land (terra nullius) until the Treaty was adopted in 1920 . The sovereignty issue was raised as early as the 17 th century, after armed clashes between several states over the capture of whales and walrus in the sea around the islands. As whale and walrus hunting declined, however, the sovereignty issue faded. ${ }^{3}$

The question of Svalbard's international legal status re-emerged when, under the Swedish-Norwegian Union (1814-1905), the authorities asked other states for their views on a possible annexation of the archipelago. The question was quickly dropped after Russia expressed its desire that the islands should remain terra nullius. ${ }^{4}$

In the 19th century, growing interest in coal extraction on Svalbard again raised the issue of sovereignty. Should the Svalbard islands be subjected to one state's sovereignty, or should an international management regime be created for the archipelago ${ }^{5}$ 
Norwegian initiatives to make Svalbard a part of Norway intensified after the dissolution of its union with Sweden in 1905. However, Norway was not interested in seizing Svalbard: it wanted its acquisition to be based on international agreement.

International negotiations on Svalbard started with a conference involving three states - Norway, Sweden and Russia - held in Christiania (Oslo), 19 July-11 August 1910. Norway, Sweden and Russia proposed that Svalbard should remain terra nullius, but that a continental condominium should be established, with a "Svalbard Commission" as the main governing body, and with the chairmanship rotating among the three states. Neither France, Belgium, the UK the Netherlands nor Denmark made significant objections to the draft convention. Germany, however, expressed deep disagreement; the USA also had objections. There would be no quick and easy solution here. ${ }^{6}$

Norway, Sweden and Russia met in Christiania for a new conference on 15 January 1912. In March, Norway delivered a revised treaty draft to the other states. ${ }^{7}$ The objections raised earlier were basically unchanged, but there was still hope for a solution if all of the involved parties came together. Thus on 16 June 1914, Norway took the initiative to convene a third conference in Christiania. However, disagreement was deep. German demands for greater influence in the management of Svalbard were strongly opposed by Russia. ${ }^{8}$ Moreover, the USA was critical to the proposed Norwegian-Swedish-Russian governance model. These interests could not be reconciled; the only agreement reached was to meet again in Christiania in February 1915. In August 1914, however, World War I erupted, and a fourth Christiania conference on Svalbard was never convened.

After the war, Norway ensured that the issue of the legal status of Svalbard quickly returned to the international agenda. On 10 April 1919, the Norwegian envoy to Paris - Fredrik Wedel Jarlsberg - informed the Versailles Peace Conference that Norway wanted negotiations on the Svalbard issue as part of the post-war peace accords. Norway's attitude had changed: it now sought full sovereignty over the archipelago. ${ }^{9}$ To the Supreme Council of the Conference, Jarlsberg announced:

\footnotetext{
Now, the experience of the successive negotiations and the labours of the Conference of 1914 seem fully to have demonstrated that there are insurmountable difficulties in the way of settling an international administration for the islands of Spitsbergen and Bear Island, starting with the idea of terra nullius, and that the only satisfactory and permanent solution will be to return this archipelago to Norway [...] The Norwegian Government is convinced that it is serving the interests of peace in submitting to the Conference this question, which has been for so long in litigation, and expresses the hope that all the Powers will agree to return this archipelago definitively to Norway, the only country which has ever exercised sovereign rights there. ${ }^{10}$
}

Although neither Norway nor Svalbard had been involved in the War, the Conference did discuss the issue. The Allies were aware that the Norwegian merchant fleet had suffered heavy wartime losses. In addition, the USA now wanted final clarification of the Svalbard sovereignty issue. On 7 July 1919, the Conference established a 
separate Spitsbergen Commission. The Commission had one member from each of the major powers (the USA, Japan, Italy, France and the UK) and held 17 meetings from 18 July to 22 October $1919 .{ }^{11}$

According to the Norwegian draft treaty to the Commission, Norway would have full sovereignty over Svalbard, but other states would be allowed to retain their terra nullius-rights: citizens of all states would have the same rights as Norwegians to hunt, fish and engage in certain other commercial activities. ${ }^{12}$ The Commission wanted input from other states. Denmark was positive to Norwegian sovereignty ${ }^{13}$ and the USA, France and the UK wanted neutral Norway to be granted sovereignty. ${ }^{14}$ Russia also endorsed Norwegian sovereignty, with certain reservations. ${ }^{15}$ Sweden and the Netherlands held that rather than granting Norway sovereignty over Svalbard, a mandate from the League of Nations should govern the archipelago on behalf of the international community. ${ }^{16}$ However, the Spitsbergen Commission never considered this solution. ${ }^{17}$ Without any significant controversy, the Commission reached consensus based on the Norwegian treaty proposal. On 5 September 1919 the Commission sent its recommendation to the Supreme Council of the Conference:

The archipelago being currently no man's land, everyone agrees on the need to bring to an end this state of affairs, by providing it with a defined status. To this end, two solutions have been envisaged: The first solution proposed by various Powers and certain members of the Commission, consisted in granting to Norway a mandate under the League of Nations. A second solution, requested by Norway, consisted in attributing sovereignty over the archipelago to this Power subject to certain stipulated guarantees for the benefit of the other States. Considering the major interests that Norway has with regard to Spitsbergen, its proximity to the archipelago, and the advantage of a definitive solution, the Commission rallied unanimously behind the second system, which has met on no objections from any of the most directly interested Powers. ${ }^{18}$

The Svalbard Treaty was finally approved by the Supreme Council on 21 November $1919,{ }^{19}$ signed in Paris on 9 February $1920,{ }^{20}$ and entered into force 14 August 1925. On the same day, Norway solemnly celebrated: with Norwegian flags flying over Svalbard, Minister of Justice Paal Berg mounted the simple podium in Longyearbyen and read out King Haakon's announcement that Svalbard had finally been united with the Kingdom of Norway. ${ }^{21}$

One hundred years after its adoption, the Svalbard Treaty is still in force in its original form. Thus, it is one of the few instruments of the post-First World War settlement to have survived all of the political and territorial disorder seen in Europe to the present day.

\section{Main features of the Treaty}

\subsection{Norwegian Sovereignty}

Recognition of Norwegian sovereignty over Svalbard is the key pillar of the Svalbard Treaty. Article 1 reads: 
The High Contracting Parties undertake to recognize, subject to the stipulations of the present Treaty, the full and absolute sovereignty of Norway over the Archipelago of Spitsbergen $[\ldots] .{ }^{22}$

The clarification that sovereignty is "full and absolute" merely emphasizes that there is nothing peculiar about the sovereignty: it corresponds to the customary sovereignty that is the basis of Norway's sovereignty over other territories. ${ }^{23}$ However, some important reservations apply.

A state's sovereignty generally also involves the freedom to transfer its sovereignty, in whole or in part, to other states. The Svalbard Treaty has no explicit prohibition against the transfer or suspension (wholly or in part) by Norway of its sovereignty but it is Norway's sovereignty, and not that of any other state, that is recognized by the Treaty, as was the intention of the parties. Without the consent of the other treaty parties, Norway may not transfer or suspend its sovereignty over the archipelago, withdraw unilaterally, or simply declare its abandonment of sovereignty. In such a case, the consequence would have to be termination of the Treaty itself, because Norwegian sovereignty was a fundamental underlying prerequisite. ${ }^{24}$ Basically, Norway has assumed a duty under international law to exercise sovereignty over the archipelago.

It is inconceivable that Norway should want to transfer or suspend its sovereignty over Svalbard, or withdraw from the Treaty. Admittedly, Svalbard has not been economically advantageous to Norway. Associated costs are far higher than revenue generated. Each year significant funds must be transferred from the ordinary state budget to cover expenses incurred for management of the archipelago. However, Svalbard is important for Norway for other reasons than purely economic. For security policy reasons and in order to conduct effective environmental management, Norway has been willing to make up the annual deficit entailed in sustaining an airport, hospital and a separate police force in its Arctic outpost.

\subsection{Treaty limitations on the exercise of authority}

Article 1 of the Svalbard Treaty states that recognition of Norwegian sovereignty is "subject to the stipulations of the present Treaty" as set out in the Articles that follow. Importantly, Norway is to exercise its authority on Svalbard taking into account certain substantive limitations:

First, Norway is obliged under Article 9 of the Treaty not to create or allow the establishment of naval bases or other military fortifications on Svalbard. Svalbard should also not be used "for warlike purposes". Norway has never had permanent military forces on Svalbard, except for a peacekeeping garrison stationed on the archipelago during World War II, whose mandate was solely to ensure that Article 9 was not violated. However, military activities other than the one mentioned in Article 9 are not prohibited: Svalbard is therefore not a "demilitarized" area in the international legal sense. However, with regard to military use, Norwegian sovereignty 
applies, so that only Norway may use Svalbard for military activities other than those mentioned in Article 9. ${ }^{25}$

Today, Article 9 must be interpreted so that the UN Security Council has decision-making power under Chapter VII of the UN Charter (i.e. the authority to take coercive measures against states to maintain peace and security) also in relation to Svalbard. Norway must also be entitled to defend Svalbard under Article 51 of the UN Charter. However, it is questionable whether Article 9 bars Norway from using Svalbard territory to defend other parts of Norwegian territory in case of war.

Second, Article 8 includes provisions on taxation: fees and taxes collected on Svalbard shall benefit only Svalbard, not mainland Norway, and shall not be higher than necessary for that purpose. Accordingly, there are separate tax rates for Svalbard, although the level of taxation does not cover the costs of managing the archipelago.

Third - and especially important - are the substantive limitations which the Treaty places on Norway with regard to the treatment of foreigners. Discrimination on the basis of nationality is prohibited in relation to certain activities, giving foreigners equal rights to hunting, fishing and mining in Svalbard and its territorial seas (Article 2). Article 3 determines that nationals of all treaty parties have equal rights to access and enter Svalbard. Further, Norwegian citizens shall not enjoy favourable treatment with respect to taxes on imports or exports to/from Svalbard. Article 4 stipulates that radio stations established on Svalbard shall be open to citizens of all treaty parties. According to Article 5, paragraph 2, environmental measures shall always be applicable equally to the nationals of all the contracting parties without any exemption, privilege or favour whatsoever, direct or indirect, to the advantage of any one of them. Finally, Article 7 stipulates that citizens of all treaty parties shall have equal standing as regards the acquisition and exercise of property and mining rights. The Treaty's prohibition of discrimination thus means that no country's citizens (including Norwegians) are to be favoured over subjects of other treaty parties. ${ }^{26}$

In one respect, the Svalbard Treaty therefore bears similarity to an agreement that applies on the Norwegian mainland: the Agreement on the European Economic Area (EEA Agreement). ${ }^{27}$ Under the EEA Agreement, there is to be equality between the nationals of the EEA countries as regards the right to conduct business activities, and, inter alia, free cross-border movement of persons and goods. The Svalbard Treaty, however, is markedly different from the EEA Agreement since Norway does not enjoy equal rights in the territories of states parties to the Svalbard Treaty.

\subsection{Scientific research}

Article 5, second paragraph, of the Svalbard Treaty anticipated agreements to govern the conditions for scientific research:

Conventions shall also be concluded laying down the conditions under which scientific investigations may be conducted in the said territories. 
Any treaty party may propose that negotiations on such agreements be initiated. ${ }^{28}$ However, no state has ever proposed the establishment of a research convention. As long as no such agreements exist, it is up to Norway - by virtue of its sovereignty - to establish the conditions for scientific research on Svalbard. This is done, inter alia, through the Svalbard Environmental Protection Act. ${ }^{29}$ The basis for regulating research activities in Svalbard has thus been Article 1 of the Treaty rather than Article 5.

Certain activities on Svalbard are covered by the principle of equal treatment. Research is not explicitly mentioned as one such activity, nor did the Treaty negotiations indicate that all treaty parties should have equal rights to conduct research. ${ }^{30}$ However, some states, including China, consider that research is covered by the equal-treatment requirement. ${ }^{31}$

In any case, the Norwegian authorities have chosen to facilitate international polar research and education on Svalbard since the 1960s, with participation from many nations. The policy has been to give scientists from all nations equal working conditions. Ny-Ålesund has become Svalbard's research hub; the ambition is to continue to facilitate relatively extensive international research activity on the archipelago. ${ }^{32}$

\subsection{Environmental protection}

Svalbard is an unparalleled, largely unspoilt wilderness area. Wildlife on the archipelago is unique in Europe. There are also cultural remains, notably from mining and trapping, dating back hundreds of years. ${ }^{33}$

Aware of Svalbard's unique environmental status, the treaty makers adopted the following provision in Article 2:

Norway shall be free to maintain, take or decree suitable measures to ensure the preservation and, if necessary, the reconstitution of the fauna and flora of the said regions, and their territorial waters $[\ldots]$.

This indicates that Norway shall use its sovereignty to take active measures to protect the environment of Svalbard, and has also been interpreted as such by Norway. In the preparatory works of the Svalbard Environmental Protection Act - under which large areas of Svalbard have been protected as national parks, nature reserves, etc. - Article 2 is understood as a directive from the treaty parties to Norway for environmental protection.

\section{Norway's policy towards Svalbard}

Until the late 1950s, the Soviet Union was the only treaty party other than Norway to have a significant presence on Svalbard and to take advantage of the rights accorded by the Svalbard Treaty. The USSR was not recognized as a state when the Treaty was signed and did not take part in drafting its provisions. It first had the opportunity to join the Treaty in 1935, after the last of the signatory powers - the USA - recognized the Soviet Union as a state. ${ }^{34}$ 
However, throughout the 1960s, there was increasing multinational interest in Svalbard. After petroleum discoveries were made in the Arctic, foreign oil companies turned to Norway, desiring to explore for oil on the continental shelf around the archipelago. At the same time, a growing awareness of environmental issues also extended to Svalbard and other Arctic areas. Moreover, the development of the law of the sea gave rise to new legal issues. What rules of international law would now apply in the sea beyond Svalbard's territorial waters? Had Norway - as per the new law of the sea - sovereign rights on the continental shelf and in a 200-mile zone around the archipelago? Or were the sea and seabed beyond Svalbard's territorial waters subject to the treaty regime, requiring Norway to treat citizens of all treaty parties equally and limiting Norway's powers of taxation? Old and new international law were on a collision course, with no obvious solution in sight.

The developments prompted a new policy for Svalbard. Based on the government's White Paper on Svalbard, the Norwegian Parliament for the first time had an overall review of its Svalbard policy in $1975 .{ }^{35}$ Since then, the government has, approximately every ten years, submitted White Papers on Svalbard to the Parliament. ${ }^{36}$ The objectives were first explicitly formulated in the 1980s; in the most recent (2016) White Paper on Svalbard - 30 years later - the main objectives are formulated in almost identical wording:

- consistent and firm enforcement of sovereignty

- proper observance of the Svalbard Treaty and control to ensure compliance

- maintenance of peace and stability in the area

- preservation of the area's distinctive natural wilderness

- maintenance of Norwegian communities in the archipelago. ${ }^{37}$

A few comments: First, consistent and firm enforcement of sovereignty is in accordance with the Treaty obligations. There shall be no doubt that Svalbard is Norwegian territory. Active enforcement on the part of the Norwegian authorities has also been necessary for effective implementation of the Treaty's obligations, including by ensuring good and predictable management of the area's resources and environmental condition.

Second, an overarching goal has been to ensure that the Svalbard Treaty is complied with, as well as to maintain peace and stability on the archipelago. Both objectives are also anchored in national interests. A small state like Norway depends on international relations built on legal norms, not power relationships. Svalbard's geographical location is highly pertinent here: Norwegian Svalbard policy shall contribute to peaceful development and avoidance of conflicts in the High North.

Conservation of Svalbard's distinctive natural environment has been another overarching goal of Norway's policy towards Svalbard. With the exception of a few human settlements, the archipelago is basically a vast wilderness area. The 2016 White Paper states that the extent of untouched ecosystems shall be maintained and that Svalbard shall continue to be one of the world's best-managed wilderness areas. ${ }^{38}$ 
An overarching goal has also been the maintenance of Norwegian settlement on Svalbard. As long as there has been a permanent Russian presence on Svalbard, it has been the intention of the Norwegian authorities to support a Norwegian population there as well. Efforts have thus focused on creating a viable community in Longyearbyen, which is no longer a one-industry society. In fact, coal mining - which for decades was the only activity on Svalbard (apart from hunting), and the reason why in the late $19^{\text {th }}$ and early $20^{\text {th }}$ centuries a regime for Svalbard was thought desirable has been on the decline for a long time. Over the past 20-30 years, a restructuring process has ensured better public services and more diverse commercial activities, including tourism. However, the goal has not been to promote population growth, which could trigger the need for massive investment. ${ }^{39}$ It would seem that ensuring a Norwegian presence on Svalbard has not been an end in itself; the presence of Norwegian residents has primarily contributed to effective assertion of sovereignty, as a counterweight to the presence of nationals of other states (Russia).

\subsection{Legislation \\ 4.1.1 Introduction}

By virtue of its sovereignty, Norway may use the same tools for policy implementation in Svalbard as elsewhere in Norway. Regarding economic instruments, business initiatives seen in Longyearbyen in recent decades would not have been possible without large remittances from Oslo. State ownership in various companies has also been important for maintaining permanent Norwegian communities on the archipelago. Wholly owned state limited companies include Store Norske Spitsbergen Kullkompani AS, Kings Bay AS, Bjørnøen AS and the University Centre in Svalbard (UNIS). Store Norske owns hundreds of houses in Longyearbyen and has operated coalmines in Svalbard for over a hundred years. The government also owns almost all of the land on Svalbard; less than one per cent of the land area is owned by others, including the Russian state-owned coal company Trust Arktikugol.

Nevertheless - on Svalbard as elsewhere - it is the adoption and enforcement of legislation that has been the main public instrument for managing Svalbard. As early as 23 April 1925, the Ministry of Justice and Police presented a recommendation for a Svalbard Act, approved by royal decree the same day. ${ }^{40}$ From the day that Norway officially assumed sovereignty over the archipelago - on the entry into force of the Svalbard Treaty 14 August 1925 - the Svalbard Act also came into force. Since then, the main task of the Norwegian authorities has been to provide the necessary regulation to manage activity on and around the archipelago.

\subsubsection{Duty to legislate}

The Svalbard Treaty imposes an explicit duty to legislate. Pursuant to Article 8, Norway shall adopt mining regulations for the archipelago. Prior to the entry into force of such regulations, Article 8, paragraph 4, stipulates that Norway shall consult 
other states. When the work on mining regulations for Svalbard started in 1919, Norway first presented a draft Mining Code to Sweden. Sweden raised objections, but eventually came to terms with Norway. Norway also negotiated with the UK before a revised draft for a Mining Code was put forward to all treaty parties in September 1921. Then, however, the Netherlands and Denmark raised objections. Norway threatened to refer the work to such commissioning as prescribed by Article 8, paragraph 4, spurring Denmark and the Netherlands to withdraw their objections.

Under Section 4 of the Svalbard Act, the Mining Code for Svalbard was adopted by royal decree on 7 August $1925 .{ }^{41}$ The Mining Code is applicable to the whole of Svalbard and includes provisions on how to acquire natural reserves of coal, soils, oils, other minerals and rocks, as well as how mining operations shall be conducted.

While it is indeed a Norwegian regulation, it is uncertain whether Norway may make changes to the Mining Code unilaterally, or whether - even concerning the slightest modification to the regulations - it is obliged under Article 8, paragraph 4, of the Treaty to consult the other treaty parties again. Norway has not adopted significant changes to the Mining Code since 1925, but on three occasions, the regulation fees were adjusted to remove the effect of price inflation. The first two times this happened, in $1971^{42}$ and $1987,{ }^{43}$ the Soviet Union protested, holding that none of the Mining Code's provisions could be changed without the approval of the other treaty parties. ${ }^{44}$ However, with the latest inflation adjustment in force from 1 January $1993,{ }^{45}$ no protest was lodged from other states - indicating acceptance that Norway may make minor changes to the Mining Code without triggering the duty to engage in diplomatic discussions under Article 8, paragraph 4.

\subsubsection{Application of legislation to Svalbard}

Section 2 of Svalbard Act provides the methodological starting point for assessing whether Norwegian laws apply to Svalbard. It provides that only Norwegian private law, criminal law and rules concerning the administration of justice automatically apply to Svalbard (unless exceptions are made). Special provisions are required if public law regulations other than criminal law and rules concerning the administration of justice shall be applied in the archipelago.

An important argument for maintaining the principle in Section 2 has been that enforcement opportunities in Svalbard are limited, due in part to factors such as geographical location, distance and climatic conditions ${ }^{46}$ The limited resident population, the relatively modest management apparatus necessary for governance and control, etc., have also dictated limitations to the scope of legislation.

However, developments in recent decades - with Svalbard becoming a more modern society, at least as regards Longyearbyen - spurred discussion as early as the 1990s whether the principle in Section 2 of the Svalbard Act should be reversed so that all Norwegian legislation should also apply to Svalbard. ${ }^{47}$ Today the government's view is that legislation on Svalbard shall be as similar to mainland Norway's 
as possible, and that, as a rule, new regulations shall be made applicable in Svalbard unless special circumstances dictate otherwise or unless exemptions or adaptations are needed. ${ }^{48}$ However, Section 2 of the Svalbard Act continues in its original form. ${ }^{49}$ When a law is passed which does not concern private law, or which deals with criminal law or regulations concerning the administration of justice, it must be specifically decided whether the law in question shall apply to Svalbard too.

One argument for upholding Section 2 in its original form is that the authorities must carry out special assessments on whether public law shall apply to the archipelago or not. If the principle in Section 2 is removed, inattention on the part of the legislature might lead to legislation applying to Svalbard that is neither desirable nor necessary. Conditions in Svalbard are still special compared to elsewhere in Norway. An example of this is the lack of entry restrictions. In accordance with Article 3 of the Svalbard Treaty, Norway's Immigration Act has not been applied to Svalbard; ${ }^{50}$ there are no visa obligations or requirements for residence and work permits for foreign citizens upon entry to Svalbard. When anyone may freely come and stay in Svalbard, it is obvious that the state cannot introduce the same legislation there as elsewhere in Norway. Despite state provision of a certain level of welfare benefits, important acts, such as the Social Services Act, ${ }^{51}$ do not apply in Svalbard. ${ }^{52}$

Moreover, legislation for the archipelago shall not be contrary to the obligations that Norway has under the Svalbard Treaty. If all public law were to apply automatically, this would entail a greater risk that Norway might, by accident, make applicable legislation that violates the Treaty. Of course, such provisions could be revoked by amending the law, but the government has clearly stated that this is to be avoided:

[If] public law were applied to Svalbard without special determination, a lack of vigilance may result in inadvertent application of a Norwegian rule, possibly with violations of international law and/or foreign policy adverse effects. ${ }^{53}$

It is beyond the scope of this article to provide anything more than a summary of the main laws applicable to Svalbard today. Besides the Svalbard Act, the Svalbard Environmental Protection Act should also be mentioned. ${ }^{54}$ The tendency is for more and more laws and regulations to be applied to the archipelago: the Competition Act was applied in $2009 ;^{55}$ the Harbour and Fairways Act in $2010 ;^{56}$ the National Security Act in $2013 .{ }^{57}$ In 2015, the Ministry of Health and Care Services also made several health laws and regulations applicable to Svalbard. ${ }^{58}$

\subsubsection{Regulations}

Section 4 of the Svalbard Act contains an important provision: the government has competence to establish regulations for Svalbard in several administrative areas particularly important for the management of Svalbard. Mining is mentioned specifically; Section 4 was the legal basis used by the Ministry of Commerce when the Mining Code was adopted in 1925. Over the years, various other ministries and lower administrative bodies have adopted regulations for Svalbard pursuant to Section 4. 
Moreover, regulations affecting Svalbard have been adopted based on other acts than the Svalbard Act. A relevant example is regulations relating to the fishery protection zone, ${ }^{59}$ adopted pursuant to Section 1 of the Economic Zone Act. ${ }^{60}$

\subsection{Administration}

In addition to legislation, extensive administrative arrangements for Svalbard have been established. Various ministries deal with and decide cases relating to the archipelago. In 1965, the Interministerial Committee on Svalbard was established as a consultative and coordinating body ${ }^{61}$ (from 1971, the Interministerial Committee on the Polar Regions). ${ }^{62}$ The Committee meets about ten times a year, with representatives from relevant ministries that deal with polar issues (including the Ministry of Justice and the Ministry of Foreign Affairs).

In addition to central management, many administrative tasks have been added to Svalbard locally. Ever since the Treaty entered into effect in 1925, the Governor of Svalbard has carried out important functions. According to Section 5 of the Svalbard Act, the Governor has the same authority as a county governor in Norway; he or she also serves as chief of police and notarius publicus. Police and prosecution tasks are central to the Governor's work, as is work related to rescue and emergency response. Further, the Governor has responsibility for environmental protection work on Svalbard.

There has been a debate on whether a municipal or county administration should be introduced in Svalbard, akin to the system on the mainland. ${ }^{63}$ It remains to be seen whether Norway's northernmost region will ever obtain such status - the current tendency is to reduce rather than increase the number of such administrative units in Norway. However, in 2002 the Longyearbyen Community Council was established, with many of the same responsibilities as a mainland municipality. ${ }^{64}$

\section{Disputes}

\subsection{Sovereignty not contested}

On several occasions the Svalbard Treaty has been a source of disagreement and diplomatic friction between Norway and other treaty parties. Notably, some states have held that Norway has not in all respects complied with its obligations under the Treaty, especially concerning how non-Norwegians have been treated, and also with regard to the administrative and regulatory measures that Norway has implemented on and in the sea adjacent to the archipelago.

However, Norway's sovereignty over Svalbard has not been disputed or challenged. A sole incident occurred in November 1944, when Soviet Foreign Minister Molotov, in a meeting with his Norwegian counterpart Lie in the Kremlin, advocated that Svalbard be subject to joint Norwegian-Soviet rule, and that Bear Island be ceded to the USSR. The Soviets felt trapped at sea and wanted their Northern Fleet to 
have free access to the oceans. Molotov's proposal marked the start of the "Svalbard crisis", which lasted until 1947. The Norwegian government was initially not directly dismissive of the Soviet proposals, and even launched proposals for treaty amendments that included joint Norwegian-Soviet defence measures. With the beginning of the Cold War, however, pressure was exerted on Norway both from the USA and Britain, and in 1947, Oslo rejected further negotiations on a new Svalbard arrangement.

The USSR never resumed the case ${ }^{65}$ If there is one thing the "Svalbard crisis" shows, it is that Norway cannot be pushed too far regarding sovereignty issues; whoever challenges Norwegian sovereignty on Svalbard challenges not only Norway, but the interests of other powerful states that see themselves served by the fact that Norway possesses sovereignty over the archipelago. It is not a matter of indifference, to the USA, for example, whether it is Norway or Russia that has sovereignty over Svalbard. Any entity that tramples too closely on Norwegian sovereignty also tramples too closely on the interests of other states.

\subsection{Geographic scope of application}

Even though other states have not challenged Norwegian sovereignty over Svalbard - which would have been rather odd anyway, given the unequivocal language of Article 1 of the Treaty - several states have protested against Norway's exercise of authority on the territory and in the adjacent sea and seabed areas of the archipelago. The days prior to the celebration of the Treaty centenary on 9 February this year are a case in point. The prelude to the anniversary was duly marked in Norway, with television shows and news reports about Svalbard. A few days before the anniversary itself, however, Russian Foreign Minister Lavrov sent a letter to his Norwegian counterpart, criticizing Norwegian governance of Svalbard. The letter, published on the Russian Foreign Ministry's website on 4 February, notes several points where Russia considers Norway in violation of the Svalbard Treaty. ${ }^{66}$ This criticism concerns, inter alia, restrictions on helicopter use on Svalbard, and the purported illegal establishment of the fishery protection zone. Lavrov also referred to the unduly large expansion of environmental protected areas and to Norway's "deportation procedures" for Russian citizens. The tone of the letter was sharp - and it came from the highest political level. Perhaps the most serious thing for Norway was that Russia requested "talks" with Norway to solve these issues. The response from the Norwegian Ministry of Foreign Affairs was clear: dialogue with Russia on the management of any Norwegian territories was completely out of the question. ${ }^{67}$

Criticism of Norwegian governance concerning Svalbard is, however, nothing new. The USSR has raised objections on several occasions, including when Norway announced that it would construct an airport on Svalbard. ${ }^{68}$ Another aspect that has long been contentious relates to Norway's view regarding the international legal status of the sea and seabed beyond Svalbard's territorial sea. Norway maintains that 
the Svalbard Treaty does not give to other states rights beyond the territorial waters. As argued in the latest White Paper on Svalbard:

The special rules stipulated in the Treaty do not apply on the continental shelf or in zones that were created in accordance with the provisions in the United Nations Convention on the Law of the Sea governing exclusive economic zones. This follows from the wording of the Treaty and is underpinned by the Treaty's prehistory and by its development and system. ${ }^{69}$

Other states - including Iceland, the Netherlands, Russia, Spain and the UK - have nevertheless indicated that Norway's regulation of waters beyond the territorial sea should be subject to the restrictions that follow from the Treaty. ${ }^{70}$ France, Germany and the USA, among others, have yet to voice an opinion on the matter. ${ }^{71}$ Canada is said to share Norway's view on the Svalbard Treaty's scope of application: its support for the Norwegian position was incorporated in a bilateral agreement on special provisions relating to fishery surveillance and control on the high seas. ${ }^{72}$ Finland has also been supportive of the Norwegian position. ${ }^{73}$

It is Russia/the USSR that has most frequently and insistently made reservations and protested against Norwegian practice. As early as 1970, it tabled an official protest against Norway's interpretation that the Treaty regime did not extend to the continental shelf. ${ }^{74}$ Norway's position was discussed in the media after a foreign oil company approached Norway in the 1960s for permission to search for hydrocarbon deposits on the continental shelf around Svalbard. In 1977, the USSR again protested when Norway established a 200-mile fisheries protection zone around Svalbard: the Soviet Embassy in Oslo dispatched an official complaint to the Norwegian Ministry of Foreign Affairs, describing this move as "yet another step by Norway to illicitly expand its rights in the Spitsbergen area." 75

Unlike the Norwegian 200-mile zones around Jan Mayen Island and off mainland Norway, the fisheries protection zone around Svalbard is a non-discriminatory zone where Norway in practice has observed the Svalbard Treaty's principle of equal treatment. Russian vessels are permitted to fish in the zone as part of the overall bilateral cooperation on fisheries in the Barents Sea. States with a history of cod fishery around Svalbard - vessels from EU countries and the Faeroe Islands - may also fish certain quantities.

Norway's relaxed enforcement of the fishery regulations in the protection zone has helped to keep the status of the waters and seabed outside the territorial waters off the radar for decades. In the 1990s, however, Norway stepped up its regulation and enforcement activity. The coastguard seized an Icelandic trawler in 1994 for offences against the fishing regulations. In 1998, the coastguard took the Russian trawler Novokuybyshevsk under tow for fishing in a closed-off area of the protection zone. Agreement was reached between the Norwegian and Russian authorities, and the coastguard released the trawler before the entourage reached Tromsø. ${ }^{76}$ 
An equally amicable end was not in sight for the Chernigov, whose captain and shipowners were fined for grave violations of Norwegian fishery regulations in 2001. Russia demanded that the trawler be set free, as it was fishing in "waters that belong to the Svalbard archipelago [...] but outside the area in which [the Svalbard Treaty] applied, that is, where the norms of international law apply for the high seas." ${ }^{77}$

Russia's reaction to the boarding of the trawler Elektron in 2005 was more moderate. The Norwegian coastguard was already familiar with that vessel, a notorious sea-going bandit in their view. On 15 October the coastguard boarded the trawler, on suspicion of violating regulations in the area. The Elektron voluntarily agreed to follow the coastguard to Tromsø. But on the morning of 16 October, it abruptly reversed course and fled in the direction of Murmansk. The coastguard pursued the vessel, but after nearly three days on the run, the Elektron entered Russian territorial waters. The incident sparked a crisis in relations between Norway and Russia. The Russians, however, reacted calmly. This may have had something to do with the severity of the offences, as well as a sense of culpability; the crew of the Elektron had abducted two members of the Norwegian coastguard vessel's crew as they headed east. All the same, Foreign Minister Lavrov also stressed on this occasion that Russia had never officially recognized the Norwegian regime in the fisheries protection zone. ${ }^{78}$

\subsection{Snow crab and the seabed}

While Norway has allowed several other states to fish on the basis of equal treatment, fisheries management in the protection zone has been rather successful. Norway has nevertheless not been willing to treat foreigners equally with regard to operations on the continental shelf around Svalbard. This conflict has escalated in recent years. First, Russia claimed in 2015 that some of the Norwegian oil and gas licenses awarded in the Barents Sea concerned areas on the Svalbard continental shelf. In a sharp diplomatic note dated 3 March 2015, the Russian Embassy in Oslo wrote that three oil blocks in the Barents Sea were located on Svalbard's continental shelf, and that the resources in question were therefore regulated by the Svalbard Treaty. ${ }^{79}$

Second, controversy has arisen regarding the capture of snow crab on the seabed. Norway claims that the snow crab is a sedentary species, and thus covered by the continental shelf regime and not the fishing regime. Catching snow crab has been reserved for Norwegian fishermen. Vociferous protests have come from the EU and some EU member states, notably Latvia.$^{80}$ The EU considers catching snow crab as fishing - not shelf activity - and has issued licenses, including to Latvia, to catch snow crab around Svalbard. ${ }^{81}$ Norway does not accept these licenses; it was precisely such an EU license that led to the arrest of the Latvian trawler Senator in 2017 for catching snow crab around Svalbard without Norwegian permission. The shipping company and captain were convicted in the Supreme Court of Norway, ${ }^{82}$ which agreed with Norway that the snow crab is a sedentary species of 
the continental shelf within the meaning of Article 77, paragraph 4, of the United Nations Convention on the Law of the Sea (UNCLOS).$^{83}$ Like previous Norwegian criminal cases concerning foreigners' violations of fisheries regulations in the sea around Svalbard, ${ }^{84}$ the Supreme Court in the Senator case did not take a position on the issue of the geographical scope of the Treaty - which was deemed unnecessary, because it was illegal under any circumstances to catch snow crab without Norwegian permission.

The Supreme Court ruling has not stopped the EU from issuing new snow crab licences. In Latvia, however, irritation has also been directed at the European Commission, which Latvia feels should put greater pressure on Norway to accept its view on how snow crab harvests should be regulated. In a letter dated 22 December 2017, Latvia called on the Commission to act. ${ }^{85}$ First, Latvia demanded that the Commission negotiate a deal with Norway that would secure EU countries the right to catch snow crab. Second - in the event that these negotiations prove unsuccessful - Latvia demanded that the EU take international judicial action against Norway.

In a letter dated 12 March 2018, the Commission responded to both proposals set forth by Latvia. First, the Commission maintained that the EU indeed desired an agreement with Norway, but

considering recent Norwegian reactions [...] it is at present unlikely that in the immediate future a solution will be found and precautions must be taken to avoid escalation of the disagreement to the expense of pressing strategic interests in the relationship with [the Kingdom of Norway], as well as in the Arctic region. ${ }^{86}$

Concerning international judicial proceedings, the Commission noted several procedural impediments. First, that the Svalbard Treaty does not provide for any dispute-settlement mechanism. Second, that the mechanisms provided for by UNCLOS are not applicable, as the issue does not concern an interpretation or application of UNCLOS. Third, that the default dispute-settlement mechanism of the International Court of Justice (ICJ) could not be used, as the EU has no legal standing before the ICJ, and also because the EU is not a party to the Svalbard Treaty. Finally, international arbitration would require an agreement with Norway, deemed highly unlikely under the circumstances. Importantly, the Commission also argued that initiation of judicial proceedings could risk affecting the EU's bilateral relations with Norway beyond the issue at stake and could thus have significant implications. ${ }^{87}$

On 10 May 20118, Latvia then filed a lawsuit against the Commission before the Court of Justice of the European Union, claiming that the Court should annul the Commission's letter. The Court, however, held that the letter was not legally reviewable - in other words not a "challengeable act" for the purposes of Article 263 of the Consolidated version of the Treaty on the Functioning of the European Union (TFEU) ${ }^{88}$ Accordingly, Latvia's action for annulment was dismissed.

The EU did not let itself be pressured by Latvia. That did not, however, stop Latvian interests from pursuing the snow crab controversy judicially. In early April 
2020, a case record appeared in the official database of the International Centre for Settlement of Investment Disputes (ICSID), an international arbitration institution for dispute resolution and conciliation between international investors. ${ }^{89}$ ICSID allows international investors to bring compensation cases directly against a state if they believe it has violated applicable international law in its treatment of investors. The legal basis for the lawsuit is a bilateral investment agreement Norway concluded with Latvia in the 1990s. ${ }^{90}$ The Latvians claim that Norway's actions regarding the catching of snow crab are discriminatory, and that they have been the victim of a campaign of harassment which has destroyed the value of the company's investments in crab fishing. They also argue that Norwegian courts have made arbitrary and inconsistent decisions, violating their right to a fair trial. ${ }^{91}$

It is easier for an investor to take a case to arbitration than the state of Latvia. A case brought by Latvia would have far greater diplomatic consequences. However, an ICSID panel does not have the jurisdiction to test the validity of Norwegian regulations - only to adjudge compensation for possible losses inflicted as a result of not being allowed to catch snow crab. This is, however, completely new territory for Norway, which has never before been sued before the ICSID.

\subsection{Who is right?}

Who is right about the issue of whether the Svalbard Treaty applies beyond Svalbard's territorial waters? First, some clarifications are in order.

First, the assertion proposed by Russia, and formerly the Soviet Union, that Norway is prevented under international law from establishing a 200-mile zone around Svalbard and thus from regulating fishing outside its territorial waters must be rejected. The fisheries protection zone is not illegal. This would only hold if the coastal state's right to establish maritime zones did not apply to the specific case of Svalbard. ${ }^{92}$

The Svalbard Treaty does not specifically prohibit Norway from establishing maritime zones around Svalbard. On the contrary, in several places reference is made to Svalbard's "territorial waters". That the Treaty makes no explicit mention of other maritime zones is simply because in 1920, neither the 200-mile zones nor the continental shelf existed in international law.

Are there any other rules under international law debarring Norway from establishing maritime zones? According to UNCLOS Article 121, paragraph 3, "[rocks] which cannot sustain human habitation or economic life of their own shall have no exclusive economic zone or continental shelf." The Svalbard archipelago's Spitsbergen, North-East Land, Edge Island, etc., can sustain human habitation and/or economic life of their own, and they are undoubtedly not "rocks". However, based on the ruling of the arbitral tribunal in the South China Sea case - in which size was not deemed decisive in determining whether an island is a "rock" for the purposes of Article 121(3), ${ }^{93}$ Bear Island, Hope Island and Abel Island should arguably not 
generate their own 200-mile zone or continental shelf. But whether these islands are subject to the exception in UNCLOS Article 121(3) is inconsequential, as nearly all of the fishery protection zone off Svalbard lies within 200 nautical miles of Spitsbergen. ${ }^{94}$

Second, the assertion (previously) held by Norway that Svalbard does not have its own continental shelf must also be rejected. The argument that Svalbard simply sits on the continental shelf of mainland Norway, with no continental shelf of its own, was first advanced by Norway in the 1970s. ${ }^{95}$ In Report No. 40 to the Norwegian Parliament (1985-86) concerning Svalbard, it was also argued that there exists a "continuous" continental shelf area in Skagerrak, the North Sea, the Norwegian Sea, the Barents Sea and the Arctic Ocean, and that Norwegian legislation pertaining to the continental shelf also applies to the continental shelf off Svalbard, to the outer limits of its territorial waters, in the same way as it applies to the other parts of the continental shelf. ${ }^{96}$ In the legal literature it has also been argued that since the continental shelf extends unbroken from mainland Norway to Svalbard and further north, there is no separate "Svalbard shelf" subject to the Svalbard Treaty regime. ${ }^{97}$ This argumentation, however, now seems to have been abandoned by Norway. It is not mentioned in the latest government reports on Svalbard; moreover, recent state practice indicates that Norway is of the view that Svalbard indeed generates a shelf of its own. In 2006, when Norway made its submission for continental shelf areas beyond 200 miles to the Commission on the Limits of the Continental Shelf, pursuant to UNCLOS Article 76, not all of the continental shelf around Svalbard was included as shelf areas beyond 200 nautical miles. ${ }^{98}$ However, all the continental shelf around Svalbard lies beyond 200 nautical miles from mainland Norway. Thus, the continental shelf area around Svalbard was considered by Norway as the shelf appertaining to the territory of Svalbard, not mainland Norway. Furthermore, it was the baselines around Svalbard - not mainland Norway - that were used for computing the outer limits of the continental shelf in the Nansen Basin. ${ }^{99}$

To hold that the continuity of the continental shelf between Northern Norway and Svalbard and beyond precludes the existence of a distinct "Svalbard shelf", liable to special regulations under the Treaty, is hardly convincing. ${ }^{100}$ True, in a geological or geomorphological sense, the continental shelf adjacent to mainland Norway and the shelf surrounding Svalbard is the same shelf. But whether Svalbard has a shelf of its "own" or not is not a question of whether it is the same (continuous) shelf in a geological or geomorphological sense; it concerns whether one part of the continental shelf - the part surrounding Svalbard is included within the scope of the treaty regime and can therefore be labelled a distinct "Svalbard shelf". It is not up to Norway to choose whether Svalbard should count as a territory generating maritime claims. Svalbard has its "own" continental shelf just as much as Svalbard has its "own" 200-mile zone. 
Thus we are back to the issue presented in section 5.2: do the limitations on Norway's exercise of authority under the Svalbard Treaty extend to Svalbard's 200-mile zone and continental shelf? Here, legal experts differ: some say no; ${ }^{101}$ others, yes. ${ }^{102}$

\subsubsection{Wording}

There is one strong reason why the Svalbard Treaty's provisions do not apply to the continental shelf or the seas around Svalbard: the wording of the Treaty. The point of departure for the interpretation of treaties is the ordinary understanding of terms and expressions, as per the Vienna Convention on the Law of Treaties, Article 31, paragraph $1 .{ }^{103}$

According to Article 2 of the Svalbard Treaty, equal treatment with regard to fishing and hunting shall be enjoyed "in the territories specified in Article 1 and in their territorial waters". Further, according to Article 3, the non-discrimination provision shall also apply to mining activities, "both on land and in the territorial waters". There is nothing in the Treaty that says the principle of equal treatment or nondiscrimination should apply elsewhere, whether on the continental shelf or in any other maritime zones beyond the limits of the territorial sea.

The contention that the wording of the Svalbard Treaty should determine whether the sea floor and waters beyond the territorial sea should be incorporated in the Treaty regime is corroborated by the principle of interpretation according to which any limitations on sovereignty must be interpreted restrictively. If states other than Norway were to have rights, there should be explicit legal grounds to that effect. With regard to interpretation of the Svalbard Treaty, the Norwegian government has previously argued in favour of such a restrictive reading of the Svalbard Treaty. ${ }^{104}$ However, this argument seems to have been abandoned. It is not included in recent reports to the Norwegian Parliament on Svalbard. While some international judgments appear to support a restrictive principle in treaty interpretation, ${ }^{105}$ others have been more critical of this. ${ }^{106}$

\subsubsection{Purposive considerations}

According to Article 31, paragraph 1, of the Vienna Convention, the wording shall be interpreted in light of the object and purpose of the treaty in question. What about the Svalbard Treaty? On the one hand, the purpose was to give Norway sovereignty. On the other hand, the rights of other states must also be upheld. A purposeful interpretation - that the principal purpose of the Treaty was to give Norway sovereignty over Svalbard, in exchange devolving certain rights to other states - would indicate that a geographic extension of Norwegian jurisdiction should entail a corresponding extension of the rights of other states. ${ }^{107}$ Indeed, when Norway in 2003 extended its territorial waters around Svalbard from one geographic mile to twelve nautical miles, 
the rights of parties to the Treaty were also extended. As a result, the constraints laid out in the Svalbard Treaty on Norway's exercise of its authority applied across a wider area than before, and the area in which the principle of equal treatment applied had in effect also grown.

\subsubsection{Context and supplementary means of interpretation}

According to Article 31, paragraph 1, of the Vienna Convention, the wording of a treaty shall also be understood in light of that treaty's context. In conjunction with the conclusion of the Svalbard Treaty or since its establishment, no additional provisions have been created that shed further light on the Treaty's geographic scope; there is no relevant "context" to speak of.

Nevertheless, Article 31, paragraph 3 (letters b and c), of the Vienna Convention determines that subsequent practice as well as any relevant rules of international law applicable in the relations between the parties shall be taken into account in the interpretation of a treaty. Under the category of subsequent practice, it can be argued that more than forty years' practice of a non-discriminatory fisheries protection zone around the archipelago indicates that the management of the waters outside the limits of the territorial sea also falls within the scope of the treaty regime; Norwegian practice appears to be based on the non-discrimination rules of the Svalbard Treaty. However, Norway has consistently rebuffed suggestions that non-discrimination is a permanent arrangement. Norway's recent conservation of the snow crab - whereby only Norwegian vessels may catch crab - also contradicts non-discriminatory practice.

Regarding "relevant rules of international law", the issue is whether provisions in UNCLOS (or the general law of the sea) could inform the interpretation of the Svalbard Treaty concerning its geographic scope. The point is as follows. While the Svalbard Treaty envisages equal treatment with regard to fishing, mining, etc., UNCLOS approaches the management of natural resources from the opposite direction: the coastal state has the right to treat its own nationals preferentially. The rules of the Svalbard Treaty and UNCLOS are thus contradictory.

On paper, there is a conflict between the provisions of the Svalbard Treaty and those of UNCLOS; however, the latter contains no prohibition against equal treatment. Despite being a party to UNCLOS, a coastal state is not required to favour its own citizens. The fisheries protection zone is but one example. So, if one wants to argue that an older set of rules (Articles 2 and 3 of the Svalbard Treaty) should be set aside in favour of a newer set of rules (the provisions in UNCLOS), according to a mode of thinking based on UNCLOS Article 311, paragraph 2, because the former is not "compatible" with the latter, then this should apply across the board - also in relation to territorial waters. Nonetheless, Norway accepts that the basis in international law that governs Norwegian jurisdictional authority in the territorial waters around Svalbard is the Svalbard Treaty - not UNCLOS Article 2. 


\subsubsection{Supplementary means}

According to Article 32 of the Vienna Convention, supplementary means of interpretation may be evoked if the means of interpretation under Article 31 do not produce a clear result. ${ }^{108}$ The preparatory works and circumstances of the conclusion of the Svalbard Treaty offer few indications of how its geographic application should be determined. It is not unlikely that the sphere of application might have been extended if international law in 1920 had allowed states to establish maritime zones such as a continental shelf or economic zone. But this remains a matter of speculation.

Coherence considerations comprise another interpretative argument. If the Treaty's sphere of application were to be limited to Svalbard's territorial waters, this would represent a considerable departure from standard application of the law of the sea. ${ }^{109}$ This would mean that Norway has more extensive jurisdiction in the coastalstate zones beyond the archipelago's territorial waters than within. ${ }^{110}$ In the law of the sea, the opposite is normally the case; the rights of the coastal state diminish in proportion to the distance from the shoreline.

\subsubsection{Case law}

The decisions of international courts and tribunals may shed some light on whether the Svalbard Treaty covers the additions of the 200-mile zone and the continental shelf. In Petroleum Development (Trucial Coast) Ltd v. Sheikh of Abu Dhabi ${ }^{111}$ and Petroleum Development Ltd v. Ruler of Quatar, ${ }^{112}$ concessions for exclusive rights to drill for oil in territories and territorial waters did not apply to the continental shelf when Abu Dhabi and Qatar extended their jurisdiction to the shelf beyond the territorial sea. Similarly, in the 1989 case between Guinea-Bissau and Senegal, the arbitral tribunal found that a 1960 delimitation agreement applying to the territorial sea contiguous zone and continental shelf did not extend to the exclusive economic zone. ${ }^{113}$ The delimitation agreement had to be interpreted in light of the law at the time of the agreement's conclusion and the economic zone did not emerge as a legal concept until after 1960. The agreement could not, therefore, be seen as delimiting other maritime areas than those explicitly mentioned. Also, the issue at stake in the 2007 delimitation dispute between Guyana and Surinam recalls in part the latter decision. ${ }^{114}$ After their territorial sea was expanded from 3 to 12 miles, the delimitation for the previously accepted 3-mile limit did not automatically apply to the new 12-mile limit.

There is case law which gives moderate support to the view that the Svalbard Treaty can be applied beyond the territorial waters. Without providing substantive arguments, in the 2003 Oil Platforms case the ICJ decided that an older treaty (1955) between Iran and the USA applicable to "the territories of the two" also applied to the continental shelf. ${ }^{115}$ In Aegean Sea Continental Shelf, the ICJ found that when Greece had extended its jurisdiction to the continental shelf, the geographic scope 
of a reservation clause relating to its "territorial status" expanded simultaneously. The term "territorial status" was to be interpreted in light of developments in international law, an opinion that found support insofar as both the reservation and the treaty in question were assumed to be of a permanent character. ${ }^{116}$ As shown by Churchill and Ulfstein, ${ }^{117}$ traces of evolutionary interpretation approaches are also found in cases such as Dispute regarding Navigational and Related Rights ${ }^{118}$ and the Iron Rhine arbitration. ${ }^{119}$

\section{Concluding remarks}

The Svalbard Treaty recognizes Norway sovereignty over Svalbard. The Treaty is one of the few instruments from the post-World War I peace settlement negotiations still in force in its original form, having survived all the political and territorial disorder in Europe until now.

The Svalbard Treaty has posed challenges for Norway's exercise of authority primarily in two ways. First, it has been important for Norway to ensure that its legislation and enforcement measures are in line with the Treaty's substantive obligations, including its prohibition of national discrimination. Second, a challenge has emerged related to the geographical scope of the Treaty. The valuable resources in the sea around the archipelago have actualized this problem: first in the 1960s and $70 \mathrm{~s}$ in connection with managing fisheries and foreign oil companies' interests in petroleum resources; and more recently, after snow crabs appeared on the continental shelf around the archipelago.

The issue boils down to whether the Svalbard Treaty applies beyond the territorial sea. The strict wording of the Treaty pulls in the direction of the Norwegian position of limiting its geographical scope to Svalbard's territories, including its territorial sea. Considerations of object and purpose might indicate that the sea and seabed beyond the territorial waters are indeed subject to the provisions of the Treaty. However, no immediately comparable international jurisprudence exists. Case law pulls in opposing directions, for and against the Norwegian view.

There is little to indicate that Norway will rest content with a "Svalbard model" for the continental shelf, which has worked well for Russia, among others, in the fisheries protection zone. However, other states - the European Union and Latvia included - would probably not condone a regulatory model affording Norway sovereign rights shorn of the disciplines of the Treaty beyond Svalbard's territorial waters.

From the perspective of international law, Norway has a strong position in regard to the status of the sea and seabed around Svalbard. First, claims that the fishery protection zone is illegal rest on a misunderstanding of the law of the sea. Second, only the coastal state - Norway - has the right to regulate resource utilization in the sea and on the shelf around the archipelago. Thus, all that can be discussed seriously is whether the Treaty's concept of "territorial waters" shall be interpreted to include 
the 200-mile zone and continental shelf; or that the Treaty's provisions for equal treatment, etc., apply analogously beyond the territorial sea. Regarding this truly difficult question of interpretation, it is neither surprising nor legally controversial that Norway takes a stance of denial. After all, treaty law dictates that the basic command of interpretation is to construe the treaty in accordance with its terms.

\section{NOTES}

1. Published in League of Nations Treaty Series, Vol. 2, 8-19.

2. Act 17 July 1925 No 11 .

3. Nils Thuesen, Svalbards historie $i$ årstall (Oslo: Orion, 2005), 13.

4. Trygve Mathisen, Svalbard i internasjonal politikk 1871-1925 (Oslo: Aschehoug 1951), 31.

5. Geir Ulfstein, The Svalbard Treaty: From Terra Nullius to Norwegian Sovereignty (Oslo: Scandinavian University Press 1995), 38.

6. Mathisen, Svalbard i internasjonal politikk 1871-1925, 123-30.

7. Revue Génerale de Droit International Public 20 (1913), 282-97.

8. Mathisen, Svalbard i internasjonal politikk 1871-1925, 154.

9. Thuesen, Svalbards historie $i$ årstall, $84-5$

10. Meld. St. 32 (2015-2016), 18.

11. Conférence de la Paix (1919-1920), Recueil des Actes de la Conferénce, Commission du Spitsberg, Partie VII (Paris, 1924) (hereinafter: Spitsbergen Commission), 1-2.

12. Ibid, $17-8$.

13. Ulfstein, The Svalbard Treaty: From Terra Nullius to Norwegian Sovereignty, 46.

14. Willy Østreng, Økonomi og politisk suverenitet (Oslo: Universitetsforlaget, 1974), 90-1 and 95.

15. Spitsbergen Commission, 6-8.

16. Ibid, 57,72 and 89 .

17. Ibid, 16 .

18. Meld. St. 32 (2015-2016), 19.

19. Spitsbergen Commission, 111-12.

20. Original treaty parties: Denmark, France, Italy, Japan, the Netherlands, Norway, Sweden, the UK, the USA.

21. Mathisen, Svalbard i internasjonal politikk 1871-1925, 291.

22. The Svalbard Treaty is still open to accession by any state. As of today, 44 states are parties to the Treaty, with North Korea being the last state to sign (2016). Thus for the majority of states, the basis of Norwegian sovereignty is not the Treaty but customary international law, i.e. occupation of the territory with the intention to act as sovereign.

23. Carl August Fleischer. Folkerett (Oslo: Universitetsforlaget 2005), 136-37; Ulfstein, The Svalbard Treaty: From Terra Nullius to Norwegian Sovereignty, 128.

24. Ibid, 135.

25. Thus when Chechen special forces landed on Svalbard in April 2016 to use Longyearbyen Airport to reload and carry military equipment to an exercise at Russia's Camp Barneo, this constituted a violation of Article 1. On that specific occasion, however, the Norwegian Ministry of Foreign Affairs confirmed that the commercial airline carrying the soldiers had received permission from Norwegian authorities to land on Svalbard. See Aftenposten, 14 April 2016. On file with author.

26. Whether a state that accedes to the Treaty today should enjoy the equal rights under it when it was not part of the original bargain in 1920 recognizing Norwegian sovereignty is open to question. 
27 Official fournal of the European Union (OF) L 1, 3.1.1994, 3.

28. Ulfstein, The Svalbard Treaty: From Terra Nullius to Norwegian Sovereignty, 393.

29. Act 15 June 2001 No 79. See in particular Section 1, second paragraph.

30. Ulfstein, The Svalbard Treaty: From Terra Nullius to Norwegian Sovereignty, 395.

31. China's Arctic Policy. The State Council Information Office of the People's Republic of China (Fanuary 2018). Referred on http://english.www.gov.cn/archive/white_paper/2018/01/26/content_ 281476026660336.htm 1 April 2020.

32. Meld. St. 32 (2015-2016), Chapter 8.

33. Ibid, 51 .

34. However, the Soviet Union had already recognized Norwegian sovereignty over Svalbard in 1924. See Mathisen, Svalbard i internasjonal politikk 1871-1925, 277.

35. St. meld. No 39 (1974-75).

36. St. meld. No 40 (1985-86); St. meld. No 9 (1999-2000); St. meld. No 22 (2008-09); and Meld. St. 32 (2015-2016).

37. Meld. St. 32 (2015-2016), 24.

38. Ibid, 53 .

39. Ibid, 38 .

40. Proposition to the Odelsting No 48 (1925), 1.

41. On the negotiations on the Mining Code, see Mathisen, Svalbard $i$ internasjonal politikk 1871-1925, 244-50.

42. Royal Decree 11 June 1971.

43. Regulations 27 March 1987.

44. Ulfstein, The Svalbard Treaty: From Terra Nullius to Norwegian Sovereignty, 148.

45. Regulations 28 August 1992.

46. St. meld. No 39 (1974-75), 51.

47. Innst. S. No 196 (1999-2000), 9.

48. Meld. St. 32, n 10, 32, and see also St. meld. No 22 (2008-09), 34.

49. St. meld. No 22 (2008-2009), 34.

50. Act 15 May 2008 No 35.

51. Act 18 December 2009 No 131.

52. Some 40 per cent of Svalbard residents are not citizens of Norway.

53. St. meld. No 9 (1999-2000), 28.

54. Act 15 June 2001 No 79, Section 1.

55. Act 5 March 2004 No 12.

56. Act 17 April 2009 No 19.

57. Act 1 June 2008 No 24.

58. Regulations 22 June 2015.

59. Regulations 3 June 1967.

60. Act 17 December 1976.

61. Ibid.

62. Regulations 6 August 1971

63. St. meld. No 39 (1974-75), 10-12.

64. See Act 17 July 1925 No 11, Chapter 5.

65. On the Svalbard crisis, see Knut Einar Eriksen, "Svalbardspørsmålet fra krig til kald krig," in Trond Bergh and Helge O. Pharo (eds.), Historiker og veileder: Festskrift til fakob Sverdrup (Oslo: Tiden 1989), 112-62.

66. "Om Russlands utenriksminister Sergej Lavrovs brev til Norges utenriksminister Ine Marie Søreide i anledning Svalbardtraktatens 100-årsjubileum.” Press release, retrieved 1 April 2020 from www.mid.ru/. 


\section{Øystein Fensen}

67. "Klart Svalbard-svar fra UD: Går ikke i dialog med Russland om norsk territorium." Retrieved 1 April 2020 from www.highnorthnews.com.

68. Knut Frydenlund, Lille Land - Hva Nå? (Oslo: Universitetsforlaget 1982), 63-8.

69. Meld. St. 32 (2015-2016), 20.

70. Torbjørn Pedersen, "The Dynamics of Svalbard Diplomacy," Diplomacy \& Statecraft (19, 2008): 236-62, at 238-51.

71. Ibid, 239-43.

72. See Preamble to the Agreement between the Government of Canada and the Government of the Kingdom of Norway on Fisheries Conservation and Enforcement, dated 30 June 1995 (not in force). Reproduced in Proposition to the Odelsting No 3 (1995-96).

73. Pedersen, "The Dynamics of Svalbard Diplomacy," 242 and 251.

74. RolfTamnes, Oljealder (Oslo: Universitetsforlaget 1997), 311.

75. Jørgen Holten Jørgensen, Russisk svalbardpolitikk: Svalbard sett fra den andre siden (Trondheim: Tapir Akademisk Forlag 2010), 37.

76. VG, 13 July 1998 . On file with author.

77. Øystein Jensen, Noreg og havets folkerett (Trondheim: Akademika 2014), 104-5.

78. Ibid.

79. VG, 2 May 2015. On file with author.

80. See generally Robert C. Steenkamp, "Svalbard's 'Snow Crab Row' as a Challenge to the Common Fisheries Policy of the European Union," International fournal of Marine and Coastal Law (35, 2020): 106-32.

81. See Council Regulation (EU) 2017/127, Official fournal of the European Union, L 24/1, 28.1.2017, para. 35 .

82. HR-2019-282-S.

83. United Nations Convention on the Law of the Sea 1982, 1833 UNTS 397.

84. Rt. 1996 s. 624, Rt. 2006 s. 1498 and HR-2014-00577-A.

85. See Order of the General Court (Fourth Chamber), 30 fanuary 2020, in Reports of Cases, para. 1. Retrieved 10 May from https:/op.europa.eu/en/publication-detail/-/publication/ 19322934-4743-11ea-b81b-01aa75ed71a1.

86. Ibid, paras. 2-3.

87. Ibid, para. 4.

88. Ibid, paras. 50-1.

89. Peteris Pildegovics and SIA North Star v. Kingdom of Norway. All pending cases listed 1 April 2020 at https://icsid.worldbank.org/en/pages/cases/pendingCases.aspx?status=p.

90. Agreement between the Government of the Kingdom of Norway and the Government of the Republic of Latvia on the Mutual Promotion and Protection of Investments. Retrieved 1 April 2020 from https:/www.italaw.com/sites/default/files/laws/italaw11326.pdf.

91. Global Arbitration Review, 6 April 2020. On file with author.

92. Russia's argument is even more puzzling, as Russia appears to accept that Norway is entitled to a continental shelf around Svalbard.

93. South China Sea case (Philippines v. China), Award, 12 July 2016, para. 538. Retrieved 1 April 2020 from https://pcacases.com/web/sendAttach/2086.

94. For those portions which do not, see Øystein Jensen, "Defining Seaward Boundaries in a Domestic Context: Norway and the Svalbard Archipelago," Ocean Development \& International Law (2019): 243-74.

95. Jens Evensen, Muligheter og rettigheter på havbunnen. Dyphavet - et nytt ekspansjonsfelt? (Oslo: Elingaard 1970), 36-7.

96. St. meld. No 40 (1985-86), 11.

97. Carl August Fleischer, Folkerett, 139. 
98. Øystein Jensen, "Towards Setting the Outer Limits of the Continental Shelf in the Arctic: On the Norwegian Submission and Recommendations of the Commission." In Davor Vidas (ed), Law, Technology and Science for Oceans in Globalisation (Leiden/Boston: Brill 2010), 521-38.

99. Ibid.

100. Fleischer, Folkerett, 139.

101. E.g. Carl August Fleischer, "The Question of Earlier Treaty Rights Applied to the New Maritime Zones-Spitsbergen and the Law of the Sea," Iranian Review of International Relations (1978), 245-62; Peter Ørebech, "The Geographic Scope of the Svalbard Treaty and Norwegian Sovereignty: Historic - or Evolutionary - Interpretation?," Croatian Yearbook of European Law and Policy (2017), 53-86.

102. E.g. D. H. Anderson. "The Status under International Law of the Maritime Areas around Svalbard." Ocean Development \& International Law (2009), 373-384; Robin Churchill and Geir Ulfstein, "The Disputed Maritime Zones around Svalbard," in Changes in the Arctic Environment and the Law of the Sea, Myron Norquist (eds) (London: Routledge, 1992), 551-93; Ulfstein, The Svalbard Treaty: From Terra Nullius to Norwegian Sovereignty, Chapter 7.

103. 1155 United Nations Treaty Series 331. Norway has not ratified the treaty and it has no retroactive force (see Art. 4), but it is generally held that the Vienna Convention's principles of interpretation largely codify customary international law.

104. St. meld no 39 (1974-75), 7-8.

105. Case concerning the Delimitation of Maritime Boundary between Guinea-Bissau and Senegal (1989), Reports of International Arbitral Awards (20) 119.

106. Dispute Regarding Navigational and Related Rights (Costa Rica v. Nicaragua), ICf Reports (2009), 237-38 (para 48).

107. Churchill and Ulfstein, "The Disputed Maritime Zones around Svalbard," 571.

108. See Mark Eugen Villiger, Commentary on the 1969 Vienna Convention on the Law of Treaties (Leiden/Boston: Martinus Nijhoff 2009), 447.

109. Churchill and Ulfstein, "The Disputed Maritime Zones around Svalbard," 575-76.

110. Ibid.

111. Petroleum Development Ltd v. Sheikh of Abu Dhabi. In International Law Reports, Vol. 18, 1951, 144.

112. Petroleum Development Ltd v. Ruler of Quatar. In International Law Reports, Vol. 18, 1951, 161.

113. In Revue Générale dei Droit International, Vol. 94, 1990, 269.

114. Award of the Arbitral Tribunal in the Matter of an Arbitration between Guyana and Suriname (Guyana v. Suriname). In International Legal Materials, Vol. 47, 2008, 166.

115. Oil Platforms (Islamic Republic of Iran v. United States of America). ICf Reports 2003, 161, at 200 (para. 82).

116. Aegean Sea Continental Shelf (Greece v Turkey). ICF Reports 1978, 3, at 32 (para. 77).

117. Churchill and Ulfstein, "The Disputed Maritime Zones around Svalbard."

118. Dispute Regarding Navigational and Related Rights, 242 (para. 64).

119. Award in the Arbitration regarding the Iron Rhine ("Ijzeren Rijn") Railway (Belgium v. Netherlands). In Reports of International Arbitral Awards XXVII, 35 (para. 79). 